
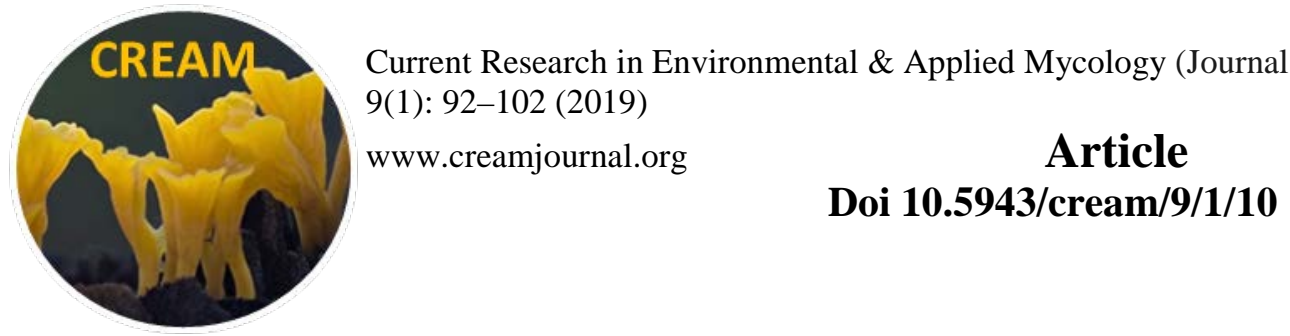

\title{
Molecular identification and in vitro propagation of arbuscular mycorrhiza from tea plant rhizosphere
}

\author{
Arofatullah NA ${ }^{1}$, Kabirun $S^{2}$, Fujiyama $K^{3}$ and Widianto $D^{2^{*}}$ \\ ${ }^{1}$ Center for International Field Agriculture Research and Education, Ibaraki University, Ibaraki, Japan \\ ${ }^{2}$ Department of Agricultural Microbiology, Gadjah Mada University, Yogyakarta, Indonesia \\ ${ }^{3}$ International Center for Biotechnology, Osaka University, Osaka, Japan
}

Arofatullah NA, Kabirun S, Fujiyama K, Widianto D 2019 - Molecular identification, and in vitro propagation of arbuscular mycorrhiza from tea plant rhizosphere. Current Research in Environmental \& Applied Mycology (Journal of Fungal Biology) 9(1), 92-102, Doi 10.5943/cream/9/1/10

\begin{abstract}
The purpose of this research was to identify arbuscular mycorrhiza spores colonizing the rhizosphere of tea plants and attempt to propagate those spores in vitro. Soil samples from the tea plant rhizosphere were sieved, and arbuscular mycorrhizal spores were isolated and identified based on a morphological and molecular approach. Five species of arbuscular mycorrhiza were identified: Acaulospora mellea, Acaulospora spinosa, Glomus ambisporum, Glomus multicaule, and Scutellospora cerradensis. Eleven arbuscular mycorrhizal sequences were obtained, the phylogenetic analysis grouped the 11 sequences into five clades, belonging to the Acaulosporaceae, Gigasporaceae, and Glomeraceae genera. Among the five species identified in this study, only two were able to germinate during co-cultivation with an Arabidopsis root organ culture host. Scutellospora cerradensis and Glomus clarum germinated after three and seven days of incubation, respectively. However, the germ tube did not develop any further and was thus unable to infect the Arabidopsis root. Nevertheless, these results provided an overview of arbuscular mycorrhizal fungal species colonizing the tea rhizosphere as well as challenges for arbuscular mycorrhiza in vitro propagation using Arabidopsis root culture.
\end{abstract}

Keywords - axenic culture - Glomeromycota - nested PCR - root organ culture - single spore sequencing - SSU rDNA

\section{Introduction}

Arbuscular mycorrhizal (AM) fungi play an important role in the process of crop production, due to their symbiosis with host plants, which can improve crop productivity. In the case of tea plants (Camellia sinensis (L.) O. Kuntze), it has been reported that inoculation with the AM fungi Glomus mosseae under different nitrogen levels promoted the growth of tea plants, including plant height, aboveground and underground biomass, as well as improved the tea quality (Qing-Hua et al. 2014). Also, AM inoculation has been shown to enhance tea resistance against root diseases (Bhutia 2013). Despite the positive effect of AM on tea plants, there have only been a few studies on the interactions of AM fungi with tea plants (Li-sha et al. 2015, Sharma et al. 2013, Karthikeyan et al. 2005), and almost no molecular information exists about the genetic diversity of AM within the rhizosphere of tea in Indonesia. Therefore, a molecular analysis of AM colonizing the tea 
rhizosphere will provide a reference for further studies of the symbiotic relationships between AM fungi and tea plants.

Continuous interaction between tea roots and rhizoflora during plant development results in the establishment of a specific microbial community (Pandey \& Palni 2004, 1997, 1996, Pandey et al. 2001, 1997) including AM fungi (Singh et al. 2008) within and around the root zone of established tea bushes. Symbiotic relationships between plants and AM in the division Glomeromycota are widespread in most terrestrial ecosystems (Koide \& Mosse 2004). Analysis of AM diversity is important for determining the soil quality in an ecosystem. Currently, molecular species determination for AM fungi is mostly based on ribosomal DNA (rDNA) sequences such as the small subunit (SSU), internal transcribed spacer (ITS) region, or the large subunit (LSU). A specific PCR primer sets (AML1 and AML2) targeting the SSU rDNA of all subgroups of AM has been developed by Lee et al. (2008) for AM species identification. These primer sets have been used in the recent study on AM fungi community in the various ecosystem (Berruti et al. 2018, Li et al. 2018, Varela-Cervero et al. 2016).

The recent advances in molecular genetics have clearly made an analysis of AM fungi communities more reliable. However, with the high genetic variation within clonal AM fungi species, it is necessary to establish monoxenic cultures of the identified clonal AM fungal spores to ensure the identity and facilitate further study on the spore development, as well as biological characteristics of the isolated spore. In vitro establishment of AM fungi in root organ culture was first successfully performed by Mosse \& Hepper (1975), using the dual culture system for growing Glomus moseae in clover root organ culture. As of today, the Ri T-DNA transformed carrot roots has been the mainstream medium for the production of in vitro AM culture (Zhang et al. 2019, Rosikiewicz et al. 2017, Bidondo et al. 2012). According to Fortin et al. (2002), 25 species of fungi have been successfully grown with monoxenic cultures using various root organ culture. This research describes the isolation and molecular identification of AM fungi in the soil sample taken from tea rhizospheres and the challenges during the in vitro culture of the isolated AM spores using the root organ of Arabidopsis, that has been widely used as a model plant. With this study, we hope to give the first overview of molecular information about AM fungi from tea rhizospheres in Indonesia that can be used as a reference for further studies on the symbiotic relationship between AM fungi and tea plants.

\section{Materials \& Methods}

\section{Morphological identification}

Soil samples for this experiment were taken from the tea plant rhizosphere located in the district of Kulonprogo, Yogyakarta province. $300 \mathrm{~g}$ of soil from six different sampling sites were collected using a spiral tipped general purpose soil auger and mixed. The AM fungal spores were extracted by wet sieving and decanting followed with a sucrose gradient centrifugation (Sieverding 1991, Daniels \& Skipper 1982). After centrifugation, the supernatant was poured through a 38- $\mu \mathrm{m}$ mesh and quickly rinsed with tap water. Spores were grouped under a dissecting microscope according to their morphological characteristics. Afterwards, these results of AM spore characterizations were then compared to the AM spore reference culture collection of the international culture collection of (vesicular) arbuscular mycorrhizal fungi (INVAM; West Virginia University, WV, USA) as well as to previous reports of AM fungi morphology which shows similarity to our isolates (Smith \& Schenck 2007, Gerdemann \& Bakshi 2009, Spain 1996, Morton 1986, Walker \& Trappe 1981).

\section{Molecular identification, sequence alignment, and phylogenetic analyses.}

A single morphologically identified spore was separated and used for molecular identification. The spore was washed with distilled water three times, afterward AM fungal DNA was extracted by crushing a single spore with a needle inside a $0.2 \mathrm{~mL}$ PCR tube and mixed with 1 $\mu \mathrm{L}$ of sterilized water. Partial 18S rDNA fragments of AM fungi were amplified by nested PCR 
(Van Tuinen et al. 1998). The first PCR was performed using universal primers NS1 (5'-GTA GTC ATA TGC TTG TCT C-3') and NS4 (5'-TTC CAT CAA TTC CTT TAA G-3') for 32 cycles (one cycle at $95^{\circ} \mathrm{C}$ for $3 \mathrm{~min}, 30$ cycles at $95^{\circ} \mathrm{C}$ for $30 \mathrm{~s}$, at $40^{\circ} \mathrm{C}$ for $1 \mathrm{~min}$, at $72^{\circ} \mathrm{C}$ for $1 \mathrm{~min}$, and one cycle at $72^{\circ} \mathrm{C}$ for $5 \mathrm{~min}$ ). The first PCR product was used as a template for the second amplification with AM specific primers: AML1 (5'-ATC AAC TTT CGA TGG TAG GAT AGA-3') and AML2 (5'-GAA CCC AAA CAC TTT GG TTT CC-3') for 32 cycles (one cycle at $95^{\circ} \mathrm{C}$ for $3 \mathrm{~min}$; 30 cycles at $95^{\circ} \mathrm{C}$ for $30 \mathrm{~s}$, at $50^{\circ} \mathrm{C}$ for $1 \mathrm{~min}$, at $72^{\circ} \mathrm{C}$ for $1 \mathrm{~min}$, and one cycle at $72^{\circ} \mathrm{C}$ for $5 \mathrm{~min}$ ) (White et al. 1990, Lee et al. 2003).

After a 10× dilution with TE buffer, the secondary PCR products were used as DNA templates for sequencing using a BigDye Terminator v3.1 Cycle Sequencing Kit (Applied Biosystems, CA, USA). At least two overlapping sequence data from each sample were collected and then recalculated with matching forward and reverse reading procedures. Reverse sequences were flipped and aligned with forward sequences. All sequences were subjected to BLAST analysis at the National Center for Biotechnology Information (NCBI; Maryland, USA) and aligned with reference sequences of AM fungi using multiple sequence comparison by a log-expectation (MUSCLE) algorithm in the molecular evolutionary genetic analysis version X software (Kumar et al. 2018). The neighbor-joining method was used for phylogenetic analysis (Saitou \& Nei 1987). Isolates used in this study and GenBank accessions are listed in Table 1. Phylogenetic trees and DNA sequence alignments were deposited in TreeBASE with submission number 24076.

Table 1 Isolates used in the phylogenetic analysis, specimens from the current study are in bold.

\begin{tabular}{|c|c|c|}
\hline Species & Isolate/ Voucher no. & GenBank Accession Number \\
\hline Acaulospora laevis & W3107 & Y17633 \\
\hline Acaulospora mellea & AM17 & MF196923 \\
\hline Acaulospora mellea & Wuy104 & FJ009670 \\
\hline Acaulospora spinosa & AM24 & MF196926 \\
\hline Acaulospora spinosa & AM48 & MF196929 \\
\hline Acaulospora spinosa & AM49 & MF196930 \\
\hline Acaulospora spinosa & W3574 & NG062381 \\
\hline Acaulospora spinosa & WV860 & Z14004 \\
\hline Diversispora epigaea & W3221 & AJ276088 \\
\hline Diversispora spurca & W3239 & AJ276077 \\
\hline Entrophospora colombiana & WV877 & Z14006 \\
\hline Gigaspora albida & FL927 & Z14009 \\
\hline Gigaspora rosea & DAOM_194757 & X58726 \\
\hline Glomus ambisporum & AM4 & MF196920 \\
\hline Glomus ambisporum & AM13 & MF196921 \\
\hline Glomus ambisporum & AM15 & MF196922 \\
\hline Glomus ambisporum & AM19 & MF196924 \\
\hline Glomus claroideum & pKL2_9a & AJ276075 \\
\hline Glomus clarum & BEG125 & AJ505619 \\
\hline Glomus clarum & UFPE08 & AJ852597 \\
\hline Glomus fasciculatum & BEG53 & Y17640 \\
\hline Glomus lamellosum & pWD100_2_6 & AJ276087 \\
\hline Glomus multicaule & AM40 & MF196928 \\
\hline Glomus caledonium & BEG20 & Y17635 \\
\hline Glomus etunicatum & pWD106_3_2 & Y17639 \\
\hline Glomus geosporum & pKL11_1a & AJ245637 \\
\hline Glomus manihotis & pWD113_4_1 & Y17648 \\
\hline Glomus mosseae & BEG69 & U96141 \\
\hline Mortierella polycephala & NBRC6335 & AB476414 \\
\hline Pacispora scintillans & pWD273_3_1 & AJ619947 \\
\hline Pacispora scintillans & pWD273_3_5 & AJ619946 \\
\hline Rhizophagus irregularis & pWD164_1_5 & AJ301859 \\
\hline Scutellospora cerradensis & AM23 & MF196925 \\
\hline Scutellospora cerradensis & AM31 & MF196927 \\
\hline Scutellospora cerradensis & SC21 & AB041344 \\
\hline
\end{tabular}




\section{Surface sterilization of spores}

Spore sterilization was performed using the filter-paper sandwich method (Mosse 1959, 1962). Spores were transferred by micropipette to a $45 \mathrm{~mm}$ diameter filter paper disc (Whatman no. 1), which was then covered by an identical disc (Fig. 1A). The sandwich was placed in a plastic filter holder (SX0004700; MilliporeSigma, MA, USA) (Fig. 1B). Both paper discs and filter holder were autoclaved $\left(121^{\circ} \mathrm{C}, 20 \mathrm{~min}\right)$. A sterilant, $2 \%(\mathrm{w} / \mathrm{v})$ chloramine $\mathrm{T}$, plus $0.02 \%(\mathrm{w} / \mathrm{v})$ streptomycin sulfate, plus a trace of Tween 20, was injected with a syringe through a $0.22-\mu \mathrm{m}$ sterile syringe filter (SLGL0250S; MilliporeSigma, MA, USA) (Fig. 1C) into the filter-paper sandwich until excess liquid emerged. A total of $20 \mathrm{~mL}$ of sterilant was used for 50 spores; the contact time was $20 \mathrm{~min}$, and the sterilant in the filter holder was replenished from the syringe three times during the sterilization process. The sterilant was removed from the spores by passing 200 $\mathrm{mL}$ of sterile distilled water through the filter paper sandwich. The sterilized spores were stored between the damp filter papers in Petri dishes at $4^{\circ} \mathrm{C}$.

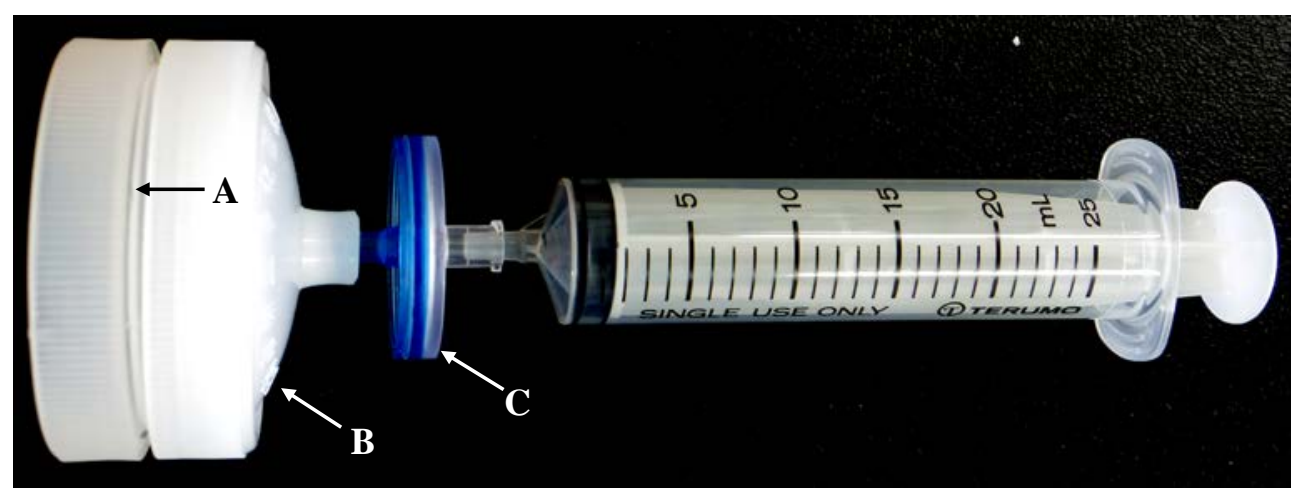

Fig. 1 - Syringe-filter arrangement for spore sterilization: A-45 $\mathrm{mm}$ diameter filter paper disc (inside filter holder), B-47 mm filter holder, and C-0.22 $\mu \mathrm{m}$ sterile syringe filter.

\section{In vitro root organ culture and $\mathrm{AM}$ spore propagation}

In vitro root organ culture was established using Arabidopsis roots. To obtain the root organ culture, Arabidopsis seed was surface-sterilized with $0.5 \mu \mathrm{L}$ of $10 \%$ Tween 20 and $1 \mathrm{~mL}$ of $2 \%$ Plant Preservative Mixture (PPM ${ }^{\mathrm{TM}}$; Plant Cell Technology, Inc., WA, USA) then washed in sterile distilled water before being placed on Murashige and Skoog (MS) agar. The plates were stored at $24^{\circ} \mathrm{C}$ in dark conditions. After seven days post-inoculation (DPI), the leaves and stems were removed, and the roots were transferred onto modified Strullu Romand (MSR) medium. After 30 DPI, the roots were fully developed and ready for AM spore inoculation. The surface sterilized AM spores were placed directly on an agar plate containing the root culture using a micropipette under aseptic conditions and incubated at $24^{\circ} \mathrm{C}$ in the dark.

\section{Results}

\section{Morphological and molecular Identification}

The isolated spores were separated based on morphological characters, including spore shape, color, and wall structures, as well as their reactions with Melzer's reagent (Fig. 2). AM spore isolates AM4, AM13, AM15, and AM19 had similar characteristics; they were non-Melzer'sreactive ellipsoid sporocarps with subtending hyphae-bearing walls that were continuous with the outer layer of the spore wall (Fig. 2A). The subtending hyphae could also be observed in the AM40 isolate; however, AM40 had a distinguishable subglobose sporocarp with a very thick outer wall (Fig. 2B), which was also not reactive with Melzer's reagent. On the other hand, the AM17 isolate showed sub globoid sporocarps with germinal walls that stained dark red purple in Melzer's reagent (Fig. 2C). The AM24, AM48, and AM49 isolates had a similar sub globoid sporocarps; however, their germinal walls stained purplish pink (Fig. 2D). The AM23 and AM31 isolates had ellipsoid 
sporocarps containing very dark red germinal wall stains in Melzer’s (Fig. 2E).

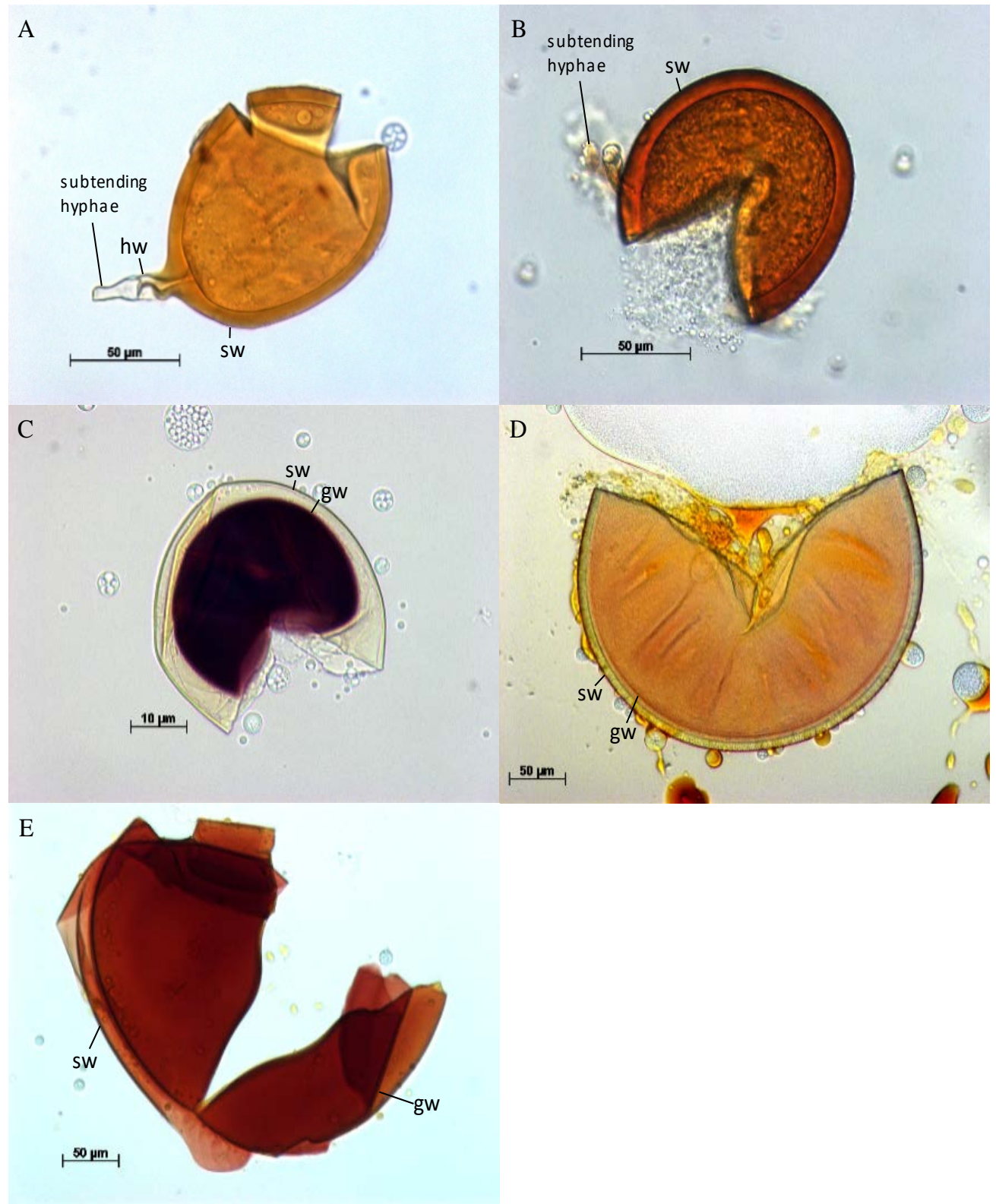

Fig. 2 - Spores of AM fungi isolated from the rhizosphere of tea. A Glomus ambisporum. B Glomus multicaule. C Acaulospora mellea. D Acaulospora spinosa. E Scutellospora cerradensis. Spores were separated and identified using morphological characters, including spore shape, color, wall structures, and reactions with Melzer's reagent; gw-germinal wall, hw-hyphae wall, and swspore wall.

For further identification and to facilitate phylogenetic tree construction, the partial $18 \mathrm{~S}$ rDNA of the spores were sequenced. A primer pair AML1/AML2 specific to AM fungi was used and successfully amplified DNA from all the species used in this study (Fig. 3), suggesting that the primers were reliable for the identification of AM fungal spores. Eleven sequences were obtained and compared with the GenBank database for molecular identification. The most similar sequences obtained using BLAST analysis and the collected AM fungal sequences were grouped into four species in three genera (Table 1). The neighbor-joining (NJ) analyses of these 11 sequences from AM fungal spores were performed with 24 other sequences from NCBI data. The phylogram obtained from the analysis grouped the isolated 11 AM spores SSU sequences into five clades (Fig. 4). 


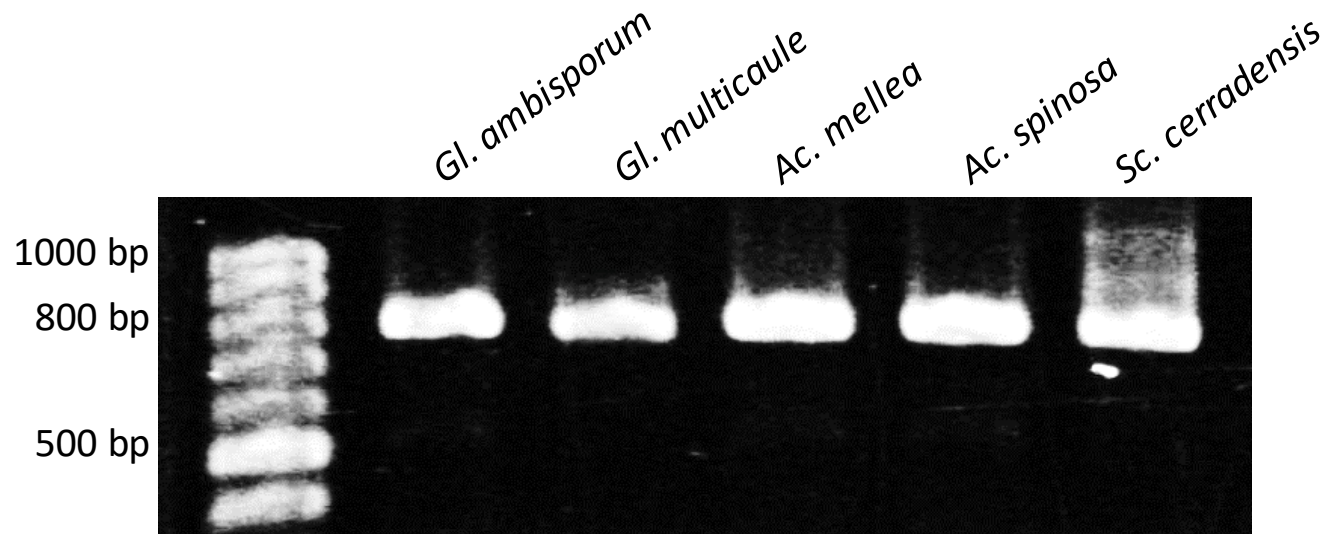

Fig. 3 - The amplification of SSU rDNA genes by using AML1-AML2 primers. SSU rRNA genes were amplified using nested PCR with NS1-NS4 universal fungal primers (1100 bp), and AML1AML2 AM specific primers (800 bp), respectively.

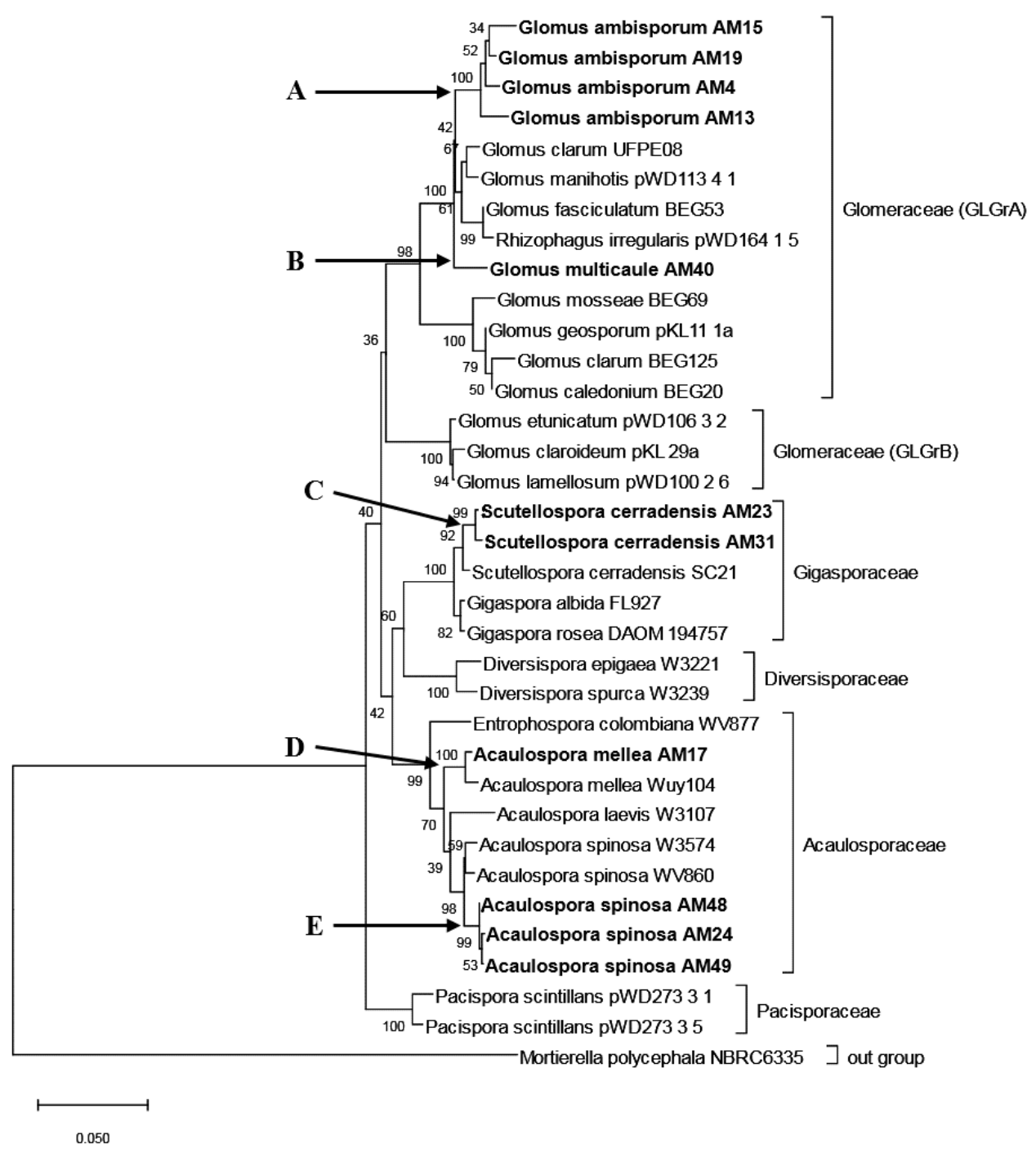

Fig. 4 - Neighbor-joining consensus phylogram for partial 18S rDNA sequence of AM fungal spores. Bootstrapping, 1000 replicates. A Glomus sp. A. B Glomus sp. B. C Scutellospora sp. A. D Acaulospora sp. A. E Acaulospora sp. B. 


\section{In vitro root organ culture and AM spore propagation}

Arabidopsis roots were grown in vitro on modified Strullu Romand (MSR) agar. After $42 \mathrm{~d}$ post-inoculation, the root organs were fully distributed on the agar plate (Fig. 5A). The root organ culture was then used as the host for AM fungi. Surface sterilization by filter-paper sandwich methods yielded 40 spores (80\%) that can be successfully sterilized, and ten spores (20\%) were contaminated, following incubation on the MSR agar plate. Two species of AM fungi were able to germinate on Arabidopsis root organ cultures; Scutellospora cerradensis germinated after three days of incubation (Fig. 5B, C), and Glomus clarum germinated after seven days of incubation (Fig. $5 \mathrm{D}, \mathrm{E})$. However, the germ tube stopped developing after germination and was thus unable to connect with the Arabidopsis root.
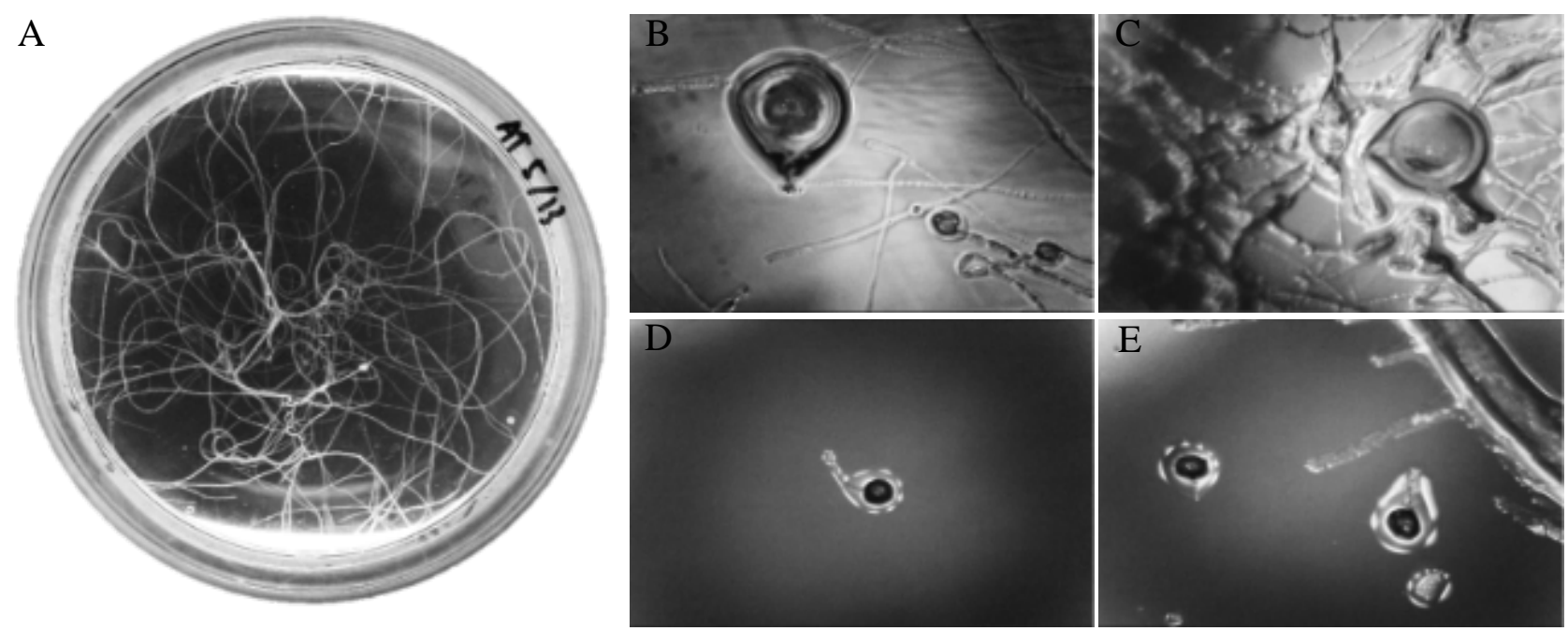

Fig. 5 - Germination of surface-sterilized spores on Arabidopsis root culture. A Arabidopsis root development after $42 \mathrm{~d}$ on MSR agar. B, C Scutellospora cerradensis germination after three days post inoculation. D, E Glomus ambisporum germination after seven days post inoculation. After cold stratification for seven days, surface sterilized spores were inoculated on Arabidopsis root cultures grown on MSR agar and incubated at $25^{\circ} \mathrm{C}$ in dark conditions.

\section{Discussion}

\section{Morphological and molecular Identification}

The morphological characters of AM4, AM13, AM15, and AM19 corresponded to the specifications for Glomus ambisporum. Smith \& Schenck. (2007) described this species as having a spore wall that consisted of two layers, neither of which was reactive in Melzer's reagent. Also, they showed that the subtending hypha at the point of attachment was 5-10 $\mu \mathrm{m}$ wide and consisted of two wall layers that were a continuation of the spore wall. The very thick outer wall of the AM40 isolate, which was non-Melzer's-reactive, was a distinctive character for Glomus multicaule (Gerdemann \& Bakshi 2009). The AM17 dark red-purple germinal wall corresponded to Acaulospora mellea (Morton 1986), while the purplish-pink germinal walls of AM24, AM48, and AM49 corresponded to Acaulospora Spinosa (Walker \& Trappe 1981). The very dark red germinal walls of AM23 and AM31, as well as their large spore sizes (250-275 $\mu \mathrm{m})$, indicated characteristics similar to Scutellospora cerradensis, which belongs to the Gigasporaceae family (Spain 1996).

The Glomus isolates (AM4, AM13, AM15, AM19, and AM40) were placed on a subclade of their own "Glomus sp. A" (Fig. 4A) and formed a clade together with Glomeraceae group A (GLGrA) reference isolates. Although the most similar sequence to AM4, AM13, AM15, AM19, and AM40 spores was Glomus clarum, these sequences were positioned on a quit distance clade in the phylogram. In addition, the AM40 clade “Glomus sp. B” (Fig. 4B) was separated into an AM4, AM13, AM15, and AM19 clade, hence indicating a species difference. This was confirmed with the differences in the morphological characteristics that identified AM4, AM13, AM15, and AM19 
spores as Glomus ambisporum, and the AM40 spores as Glomus multicaule. Moreover, Glomus isolates were randomly distributed. Stockinger et al. (2010) claimed that only longer (approx. 1500 bp) nuclear rDNA fragments (spanning SSU, ITS region, and LSU) could be successfully applied to species delineation within the GlGrAa and GlGrAb. The two Scutellospora isolates (AM23 and AM21) were clustered together in the Scutellospora cerradensis clade "Scutellospora sp. A" (Fig. 4C). The Acaulospora isolate AM17 clearly fell into the Ac. mellea clade "Acaulospora sp. A" (Fig. 4D), while AM24, AM48, and AM49 fell into the Acaulospora spinosa clade "Acaulospora sp. B" (Fig. 4E). All of the clades in the phylogram were consistent with morphological identifications; “Glomus sp. A”, “Glomus sp. B”, "Scutellospora sp. A”, “Acaulospora sp. A”, and "Acaulospora sp. B” were morphologically identified as Glomus ambisporum, Glomus multicaule Scutellospora cerradensis, Acaulospora mellea, and Acaulospora spinosa, respectively (Table 2).

Table 2 The consensus species from the morphological and molecular identifications of AM fungal spores.

\begin{tabular}{|c|c|c|c|c|c|}
\hline \multirow[b]{2}{*}{ Isolates } & \multicolumn{3}{|c|}{ The most similar sequences in GenBank database } & \multirow[b]{2}{*}{ Clade } & \multirow{2}{*}{$\begin{array}{l}\text { Consensus species } \\
\text { (molecular \& } \\
\text { morphological) }\end{array}$} \\
\hline & Species & SSU & $\begin{array}{l}\text { Sequence } \\
\text { similarity }\end{array}$ & & \\
\hline \multicolumn{6}{|c|}{ Glomeraceae } \\
\hline AM4 & Glomus clarum & AJ852597 & 813/837 (97\%) & Glomus sp. A & Glomus ambisporum \\
\hline AM13 & Glomus clarum & AJ852597 & $741 / 769(96 \%)$ & Glomus sp. A & Glomus ambisporum \\
\hline AM15 & Glomus clarum & AJ852597 & 683/698 (98\%) & Glomus sp. A & Glomus ambisporum \\
\hline AM19 & Glomus clarum & AJ852597 & 690/707 (98\% & Glomus sp. A & Glomus ambisporum \\
\hline AM40 & Glomus clarum & AJ852597 & 704/724 (97\%) & Gllomus sp. B & Glomus multicaule \\
\hline \multicolumn{6}{|c|}{ Acaulosporaceae } \\
\hline AM17 & Acaulospora mellea & FJ009670 & 707/716 (99\%) & Acaulospora sp. A & Acaulospora mellea \\
\hline AM24 & Acaulospora spinosa & Z14004 & 717/723 (99\%) & Acaulospora sp. B & Acaulospora spinosa \\
\hline AM48 & Acaulospora spinosa & Z14004 & 689/694 (99\%) & Acaulospora sp. B & Acaulospora spinosa \\
\hline AM49 & Acaulospora spinosa & Z14004 & 628/635 (99\%) & Acaulospora sp. B & Acaulospora spinosa \\
\hline \multicolumn{6}{|c|}{ Gigasporaceae } \\
\hline AM23 & $\begin{array}{l}\text { Scutellospora } \\
\text { cerradensis }\end{array}$ & AB041344 & 717/725 (99\%) & Scutellospora sp. A & $\begin{array}{l}\text { Scutellospora } \\
\text { cerradensis }\end{array}$ \\
\hline AM31 & $\begin{array}{l}\text { Scutellospora } \\
\text { cerradensis }\end{array}$ & AB041345 & 703/711 (99\%) & Scutellospora sp. A & $\begin{array}{l}\text { Scutellospora } \\
\text { cerradensis }\end{array}$ \\
\hline
\end{tabular}

The molecular identifications of AM spores belonging to the Glomus species were not consistent with morphological identifications. This was mainly due to the limited number of AM fungal sequence data in the database that were similar to the sequences from this study. Furthermore, to further validate the phylogenetic tree, several genes, as well as other characteristics, such as morphological and biochemical characters could be used. Nevertheless, the sequence data of AM fungal spores identified in this study could be used as a new reference for the identification of AM fungi colonizing roots, as reference sequences of some species such as Glomus ambisporum and Glomus multicaule were limited.

\section{In vitro root organ culture and AM spore propagation}

Macdonald (1981) reported successful AM culture in vitro by prior spore germination on the spore germination medium, followed by transferring the germinated spore to a carrot root organ culture using the agar plug technique. However, that method seemed not to be compatible with the Arabidopsis root; the spore development still stopped at the germination stage. It is unclear whether it was host incompatibility or culture conditions that caused the spore development to cease. Notwithstanding, further investigation is required to determine the cause of failure. In the previous report, Mosse \& Hepper (1975) experiencing a difficulty when establishing in vitro AM culture on red clover and tomato root organ. They observed no AM infection were developed in the media which had been sterilized in a large steam injection autoclave, although root growth was normal. 
However, when the media used for the establishment of in vitro culture was sterilized in a domestic pressure cooker which has a faster cool down time, AM infection was developed. Also, the optimization of culture conditions needs to be performed to culture the AM fungi using Arabidopsis roots as a partner. Fortin et al. (2005) reported that $\mathrm{pH}$ and temperature have a significant role in spore germination and development. Optimal temperatures seem to vary between AM fungi. Glomus mosseae and Acaulospora leavis were able to germinate between $10-18$ and $30^{\circ} \mathrm{C}$ with an optimum germination condition of $20-25^{\circ} \mathrm{C}$, while Gigaspora germinated at $10-30^{\circ} \mathrm{C}$ with an optimum germination condition of $20-30^{\circ} \mathrm{C}$ (Safir 1986). In this research, AM fungal spores were cultivated only at $25^{\circ} \mathrm{C}$. Thus, further temperature optimization should be considered.

The axenic culture of AM fungi remains a major challenge because it is far more than just a routine technique. Strict protocols must be followed to achieve it. To develop an in vitro culture system for newly isolated AM fungi, a great deal of optimization needs to be performed, such as the selection of appropriate culture systems and symbiotic host root partners, as well as the determination of appropriate culture conditions.

\section{Acknowledgments}

This research was conducted under the Biotechnology School in Asia program, funded by The United Nations Educational, Scientific and Cultural Organization and Japan Student Services Organization.

\section{References}

Berruti A, Bianciotto V, Lumini E. 2018 - Seasonal variation in winter wheat field soil arbuscular mycorrhizal fungus communities after non-mycorrhizal crop cultivation. Mycorrhiza 28(5-6), 535-48.

Bhutia LP. 2013 - Diversity of AM fungi population in tea plantation of Sikkim and exploring its friendly association with the plant. Annals of Plant Sciences 3, 638-644.

Bidondo LF, Pergola M, Silvani V, Colombo R, Bompadre J, Godeas A. 2012 - Continuous and long-term monoxenic culture of the arbuscular mycorrhizal fungus Gigaspora decipiens in root organ culture. Fungal Biology 116(6), 729-35.

Daniels B, Skipper H. 1982 - Methods for the recovery and quantitative estimation of propagules from soil. Methods and Principles of Mycorrhizal Research. The American Phytopathological Society. 29-36.

Fortin JA, Bécard G, Declerck S, Dalpé Y, Coughlan AP, Piché Y. 2002 - Arbuscular mycorrhiza on root-organ cultures. Canadian Journal of Botany 80, 1-20.

Fortin JA, Declerck S, Strullu D-G. 2005 - In vitro culture of mycorrhizas. In vitro Culture of Mycorrhizas. 3-14.

Gerdemann JW, Bakshi BK. 2009 - Endogonaceae of India: two new species. Transactions of the British Mycological Society 66, 340-343.

Karthikeyan A, Muthukumar T, Udaiyan K. 2005 - Response of tea (Camellia sinensis (L.). Kuntze) to arbuscular mycorrhizal fungi under plantation nursery conditions. Biological Agriculture and Horticulture 22(4), 305-19.

Koide RT, Mosse B. 2004 - A history of research on arbuscular mycorrhiza. Mycorrhiza 14, 145163.

Kumar S, Stecher G, Li M, Knyaz C, Tamura K. 2018 - MEGA X: Molecular evolutionary genetics analysis across computing platforms. Molecular Biology and Evolution 35, 15471549.

Lee J, Lee S, Young JPW. 2008 - Improved PCR primers for the detection and identification of arbuscular mycorrhizal fungi. FEMS Microbiology Ecology 65, 339-349.

Lee J-K, Tae M-S, Eom A-H, Lee SS. 2003 - Restriction analyses of PCR amplified partial ssu ribosomal DNA to distinguish arbuscular mycorrhizal fungi from other fungi colonizing plant roots. Mycobiology 31, 68-73. 
Li X, Xu M, Christie P, Li X, Zhang J. 2018 - Large elevation and small host plant differences in the arbuscular mycorrhizal communities of montane and alpine grasslands on the Tibetan Plateau. Mycorrhiza 28(7), 605-19.

Li-sha W, Yu W, Min L, Zhao-tang D, Run-jin L. 2015 - Arbuscular mycorrhizal fungi diversity in the rhizosphere of tea plant (Camellia sinensis) grown in Laoshan,Shandong. Biodiversity Science 17(5), 499-505.

Macdonald RM. 1981 - Routine production of axenic vesicular-arbuscular mycorrhizas. New Phytologist 89, 87-93.

Morton JB. 1986 - Effects of mountants and fixatives on wall structure and Melzer's reaction in spores of two Acaulospora species (Endogonaceae). Mycologia 78, 787-794.

Mosse B, Hepper C. 1975 - Vesicular-arbuscular mycorrhizal infections in root organ cultures. Physiological Plant Pathology 5, 215-223.

Mosse B. 1959 - The regular germination of resting spores and some observations on the growth requirements of an Endogone sp. causing vesicular-arbuscular mycorrhiza. Transactions of the British Mycological Society 42, 273-286.

Mosse B. 1962 - The establishment of vesicular-arbuscular mycorrhiza under aseptic conditions. Journal of General Microbiology 27, 509-520.

Pandey A, Palni LMS, Bisht D. 2001 - Dominant fungi in the rhizosphere of established tea bushes and their interaction with the dominant bacteria under in situ conditions. Microbiological Research 156, 377-382.

Pandey A, Palni LMS, Coulomb N. 1997 - Antifungal activity of bacteria isolated from the rhizosphere of established tea bushes. Microbiological Research 152, 105-112.

Pandey A, Palni LMS. 1996 - The rhizosphere effect of tea on soil microbes in a Himalayan monsoonal location. Biology and Fertility of Soils 21, 131-137.

Pandey A, Palni LMS. 1997 - Bacillus species: The dominant bacteria of the rhizosphere of established tea bushes. Microbiological Research 152, 359-365.

Pandey A, Palni LMS. 2004 - Tea rhizosphere: microbial diversity and characteristic features and comments on microbial communication in rhizosphere. International Journal of Tea Science 3, 285-290.

Qing-Hua Z, Li-Tao S, Yu W, Zhao-Tang D, Min L. 2014 - Effects of arbuscular mycorrhizal fungi and nitrogen regimes on plant growth, nutrient uptake and tea quality in Camellia sinensis (L.) 'O. Kuntze'. Plant Physiology Journal 50, 164-170.

Rosikiewicz P, Bonvin J, Sanders IR. 2017 - Cost-efficient production of in vitro Rhizophagus irregularis. Mycorrhiza 27(5), 477-86.

Safir GR. 1986 - VA Mycorrhizae: An ecophysiological approach. Ecophysiology of VA Mycorrhizal Plants. One_3.

Saitou N, Nei M. 1987 - The neighbor-joining method: A new method for reconstructing phylogenetic trees. Molecular Biology Evolution 4, 406-425.

Sharma C, Gupta RK, Pathak RK, Choudhary KK. 2013 - Seasonal Colonization of Arbuscular Mycorrhiza Fungi in the Roots of Camellia sinensis (Tea) in Different Tea Gardens of India. ISRN Biodiversity. 1-6.

Sieverding E. 1991 - Vesicular-arbuscular mycorrhiza management in tropical agroecosystems. Gesellschaft fur Technische Zusammenarbeit (GTZ) GmbH, Esebborn, Germany.

Singh S, Pandey A, Chaurasia B, Palni LMS. 2008 - Diversity of arbuscular mycorrhizal fungi associated with the rhizosphere of tea growing in 'natural' and 'cultivated' ecosites. Biology and Fertility of Soils 44, 491-500.

Smith GS, Schenck NC. 2007 - Two new dimorphic species in the Endogonaceae: Glomus ambisporum and Glomus heterosporum. Mycologia 77, 566-574.

Spain JL. 1996 - Scutellospora cerradensis: an ornamented species in the Gigasporaceae (Glomales) from the Cerrado region of Brazil. Mycotaxon 60, 129-136.

Stockinger H, Krüger M, Schüßler A. 2010 - DNA barcoding of arbuscular mycorrhizal fungi. New Phytologist 187, 461-474. 
Van Tuinen D, Jacquot E, Zhao B, Gollotte A, Gianinazzi-Pearson V. 1998 - Characterization of root colonization profiles by a microcosm community of arbuscular mycorrhizal fungi using 25s rDNA-targeted nested PCR. Molecular Ecology 7, 879-887.

Varela-Cervero S, López-García Á, Barea JM, Azcón-Aguilar C. 2016 - Differences in the composition of arbuscular mycorrhizal fungal communities promoted by different propagule forms from a Mediterranean shrubland. Mycorrhiza 26(5), 489-96.

Walker C, Trappe JM. 1981 - Acaulospora spinosa sp. nov. with a key to the species of Acaulospora. Mycotaxon 12, 515-521.

White TJ, Bruns T, Lee S, Taylor JW. 1990 - Amplification and direct sequencing of fungal ribosomal RNA genes for phylogenetics. PCR Protocols: A Guide to Methods and Applications. Academic Press, 315-322.

Zhang L, Fan J, Feng G, Declerck S. 2019 - The arbuscular mycorrhizal fungus Rhizophagus irregularis MUCL 43194 induces the gene expression of citrate synthase in the tricarboxylic acid cycle of the phosphate-solubilizing bacterium Rahnella aquatilis HX2. Mycorrhiza 29(1), 69-75. 